\title{
Cromossomos sexuais: a determinação do sexo
}

\author{
Paulo Goulart Junior
}

Professor de Biologia. Chefe do Departamento de Biologia da UCDB. Mestrando do Programa de Mestrado em Educação da UCDB.

\section{Introdução}

\section{Arbitrariedade do registro sexual}

Não existe em nossa espécie nenhum representante que é totalmente homem ou totalmente mulher: em cada um de nós existe o sexo oposto que sempre é encoberto pela maior quantidade de hormônios do próprio sexo.

O conceito geral da existência de uma diferenciação nítida entre macho e fêmea, criando duas entidades abstratas - o homem e a mulher - está superado pela compreensão que se tem atualmente dos mecanismos que determinam essas diferenças. Aceitamos hoje a existência de uma graduaçāo de vários estados sexuais, compreendidos entre as duas entidades sexuais.

E é assim que certos recém-nascidos apresentam alteraçōes nos seus órgãos sexuais e passam despercebidos no exame superficial realizado pelo médico ou parteira. Se nasce uma menina com clitóris (ou clítoris) desenvolvido como se fosse um pênis, geralmente é registrado sexo "masculino"

em sua ficha e certidāo de nascimento, independente de um exame mais criterioso. Os condicionamentos sociais, como roupas e jogos do sexo masculino, irão reforçar a arbitrariedade do registro, aumentando os conflitos entre a sexualidade biológica e a imposta pela educação. Mais tarde, na puberdade, pela ação dos hormônios que a identifica, o "menino" menstrua. Temos então uma mulher forçada a enfrentar a vida como homem, lutando com seus conflitos sexuais, tanto físicos como mentais, em um mundo que a recusa e não compreende as causas de seus sofrimentos.

Este trabalho procura esclarecer, dentro de uma visão cromossômica, que não é apenas o sexo genital (anatômico) que deve ser considerado. Os hormônios masculinos e femininos são determinados pelos cromossomos sexuais. Devido a esse condicionante cromossomial é que a identificação do sexo deve considerar não apenas a anatomia mas também as quatro características fundamentais seguintes:

a) morfológica: pelos órgãos genitais e das gônadas; 
b) cromossômica: pela análise dos cromossomos;

c) nuclear (citológico): pela pesquisa da cromatina sexual;

d) psicossocial: pelo meio e seu comportamento.

E qualquer indivíduo que apresente alteração em uma das quatro situaçōes é denominado "inter-sexuado".

\section{Cromossomos sexuais}

\section{Cromossomos Sexuais}

No transcurso da evolução, à raça humana foi dada a possibilidade de trazer em suas células quarenta e seis cromossomos.

Cromossomos (chromos $=$ cor; soma $=$ corpo) são filamentos microscópicos que se coram intensamente na presença de corantes citológicos.

Os quarenta e seis cromossomos das células humanas formam vinte e três pares, denominados cromossomos homólogos. Os membros de um par de homólogos se equivalem quanto à informação genética que carregam. Um membro de cada par é herdado do pai e outro membro da mãe, por obra da fertilização (também conhecida como fecundação). Destes quarenta e seis cromossomos, vinte e dois pares são pares "iguais" nos homens e nas mulheres, e são denominados autossomos. Um par é bem diferenciado no tocante homem/ mulher (macho/fêmea), por isso são denominados sexuais. Os chamados cromossomos sexuais são importantes na determinação do sexo. Normalmente, os constituintes de um par de autossomos são microscopicamente indistinguíveis, e isto também ocorre com as mulheres no par sexual, sendo este cromossomo denominado $X$, que garante à mulher a característica homogamética $(X X)$. Já nos homens, a situação difere grandemente, pois, além de possuir um cromossomo $X$, o homem possui também um cromossomo $Y$, que é menor que $X$ e não apresenta a mesma homogeneidade existente na mulher, exceto com relação a alguns genes. Isto torna os homens geneticamente diferentes das muIheres e são denominados heterozigotos. E é por essa razāo que, os homens (ou seja, com elementos fenótipos que os caracterizam como masculinos) apresentam genótipos XY, já as mulheres (ou seja, com elementos fenótipos que as caracterizam como femininas), genótipo XX.

\section{Gênese do Aparelho Reprodutor Humano}

As chamadas células germinativas embrionárias são células migradoras, derivadas do endoderma intestinal. Por volta da oitava semana da vida intra-uterina, essas células se localizam no córtex e medula da chamada Gônada Primitiva Bipotencial. É regra geral: estando presente um cromossomo Y, a gônada se diferencia para o sexo masculino, o tecido medular forma testículos típicos com túbulos seminíferos e com capacidade de secretar andrógenos, após a sua maturação. No entanto, se dois cromossomos $X$ estiverem presentes ou, mesmo se houver um $X$ e $Y$ ausente, a gônada irá se diferenciar para o sexo feminino, desenvolvendo-se o córtex 
e regredindo a medula. Se estiverem pre- to, já terá começado o seu processo de forsentes dois $X$, as ovogônias se desenvol- mação de óvulos ou células sexuais. vem na parte vertical $e$, antes do nascimen-

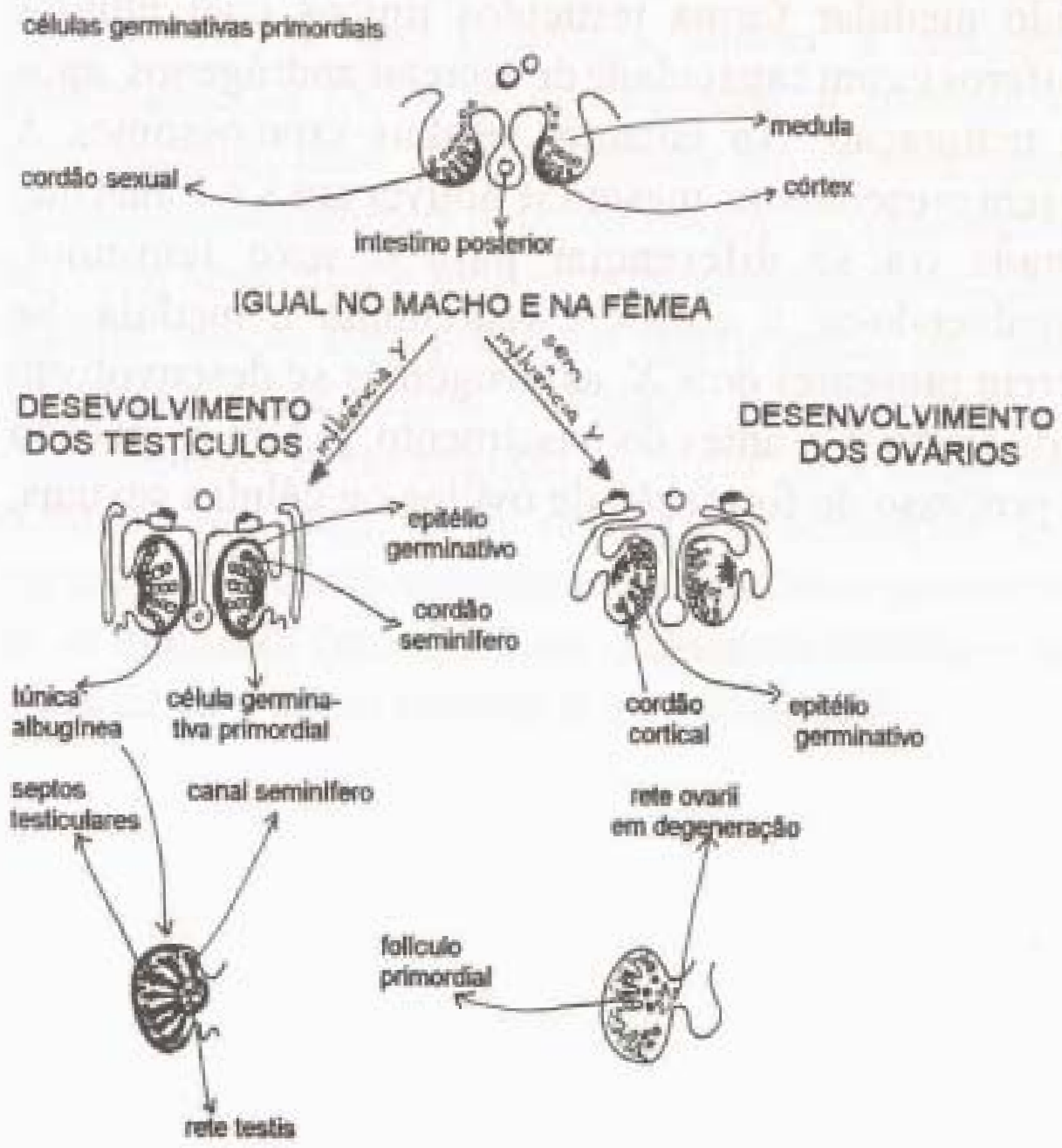

Figura 1: Diferenciação da gônoda bissexual 

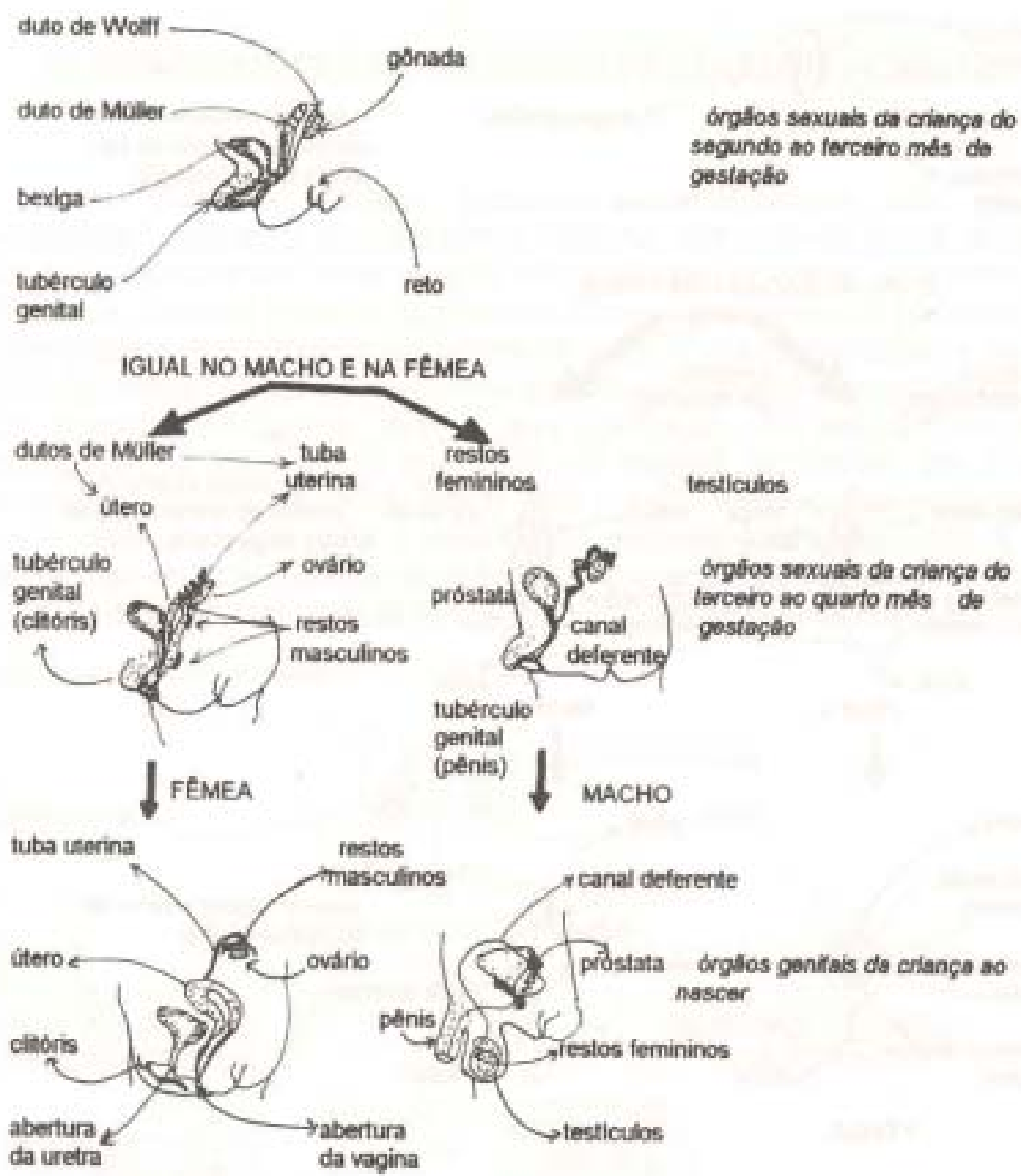

FEMEA

MACHO

Figura 2: Diferenciação dos órgãos genitais (genitália) externos 


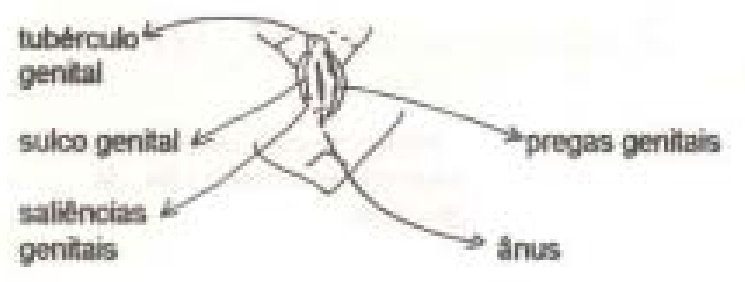

aspecto sexual externo de criança do segundo ao tercairo mas de gostagto

\section{IGUAL NO MACHO E NA FEMEA}

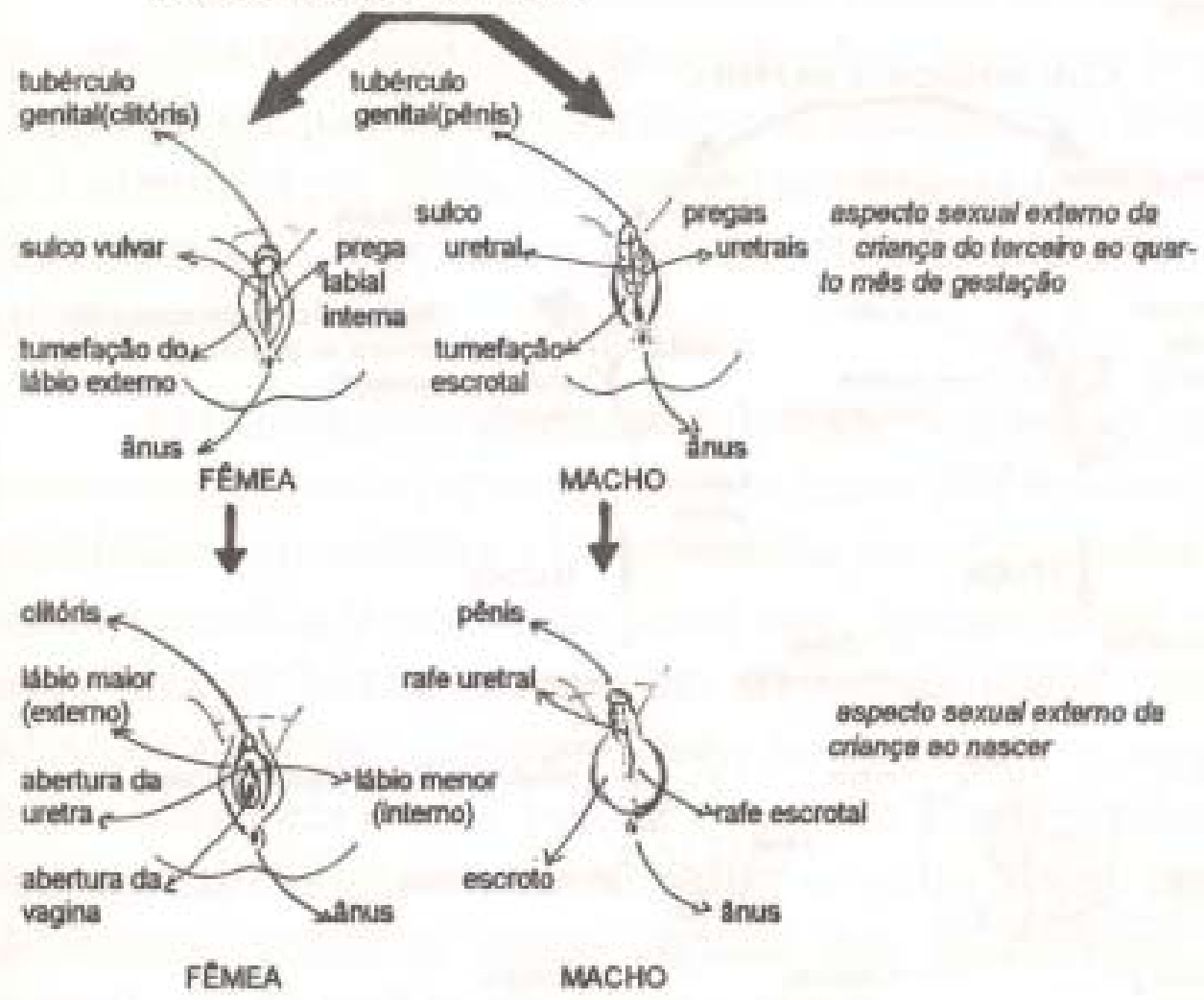

Figura 3: Diferenciação dos órgãos genitais (genitália) internos 


\section{O Cromossomo X}

O cromossomo $X$ é denominado submetacêntrico e genes nele localizados são denominados: ligado ao sexo. Graças ao seu padrão característico de transmissão, levou-se à identificação cerca de cem características ligadas ao cromossomo $\mathrm{X}$. Entre essas características importantes no cromossomo X estão:

a) Daltonismo: é uma das doenças ligadas ao sexo mais comum, onde cerca de oito por cento dos homens da raça branca apresentam a incapacidade para reconhecer as cores vermelha e verde, ao passo que, apenas cinco por cento das mulheres, apresentam tal incapacidade. Essas pessoas afetadas, possuem visão normal para o preto, branco, amarelo e azul, porém nos casos extremos desse defeito, não diferenciam vermelho e verde como cores diferentes, vendo-as como alguma das tonalidades de amarelo ou de azul ou de cinza.

b) Hemofilia: trata-se de um defeito genético, que retarda o seu portador de realizar o processo de coagulação sangüínea. Isso ocorre porque no plasma sangüíneo desses indivíduos falta a globulina (proteína) anti-hemofilica. Como essa doença é devido a um gene recessivo ligado ao sexo, uma mulher, para apresentar essa afecção, teria que receber um gene do pai (que seria hemofílico) e um da mãe (que não é hemofílica). Em virtude da raridade da doença e pelo fato de a maioria dos homens doentes não deixarem descendência, tal coincidência rarissimamente poderia ocorrer. Assim se pode explicar o fato de não se ter constatado hemofilia nas mulheres. Outra explicação, sugerida há muito e adotada por vários pesquisadores, é a de que a mulher que recebe o gene de ambos os pais morre antes do nascimento.

c) Atrofia do nervo óptico.

d) Ausência de glândulas sudoríparas, defeitos dos dentes e pêlos.

e) Cegueira noturna.

\section{O Cromossomo Y}

Trata-se de um cromossomo pequeno (em relação ao X) e classificado como acrocêntrico.

Na década de trinta, acreditava-se que o homem tanto quanto a mosca das frutas (Drosophila), era o mesmo o número de X e não a presença de Y que determinava o sexo fenotípico. Mas hoje sabemos que este depende, do homem, principalmente da presença de $Y$ e que, normalmente, qualquer um que tenha um $Y$ é fenotipicamente masculino. Entretanto, são possíveis modificaçōes do fenótipo masculino quando está presente $Y$.

\section{A Determinação do Sexo}

Os gametas femininos possuem um cromossomo $\mathrm{X}$ e, por isso, a mulher é dita homogamética.

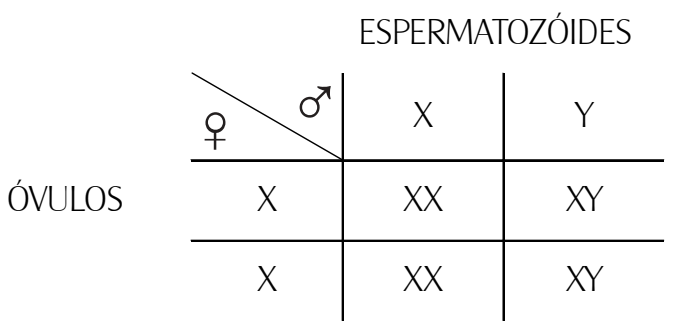

Quadro 1 
No quadro 1, fica demonstrado que o sexo do filho depende de o pai ter contribuído com um Y. A mãe, que contribuiu com $X$, não pode determinar o sexo do fiIho. Pelo quadro 1 temos uma proporção teórica que demonstra a razão de um homem para uma mulher, mas ao nascimento ela é de cerca de cento e seis homens para cem mulheres. A proporção de sexo em abortos é aproximadamente a mesma que ao nascimento (Carr, 1971).

\section{Cromatina Sexual: X Inativo}

Desde o início do século XX que já se sabe que as células masculinas diferem das células femininas em termos de cromossomos sexuais. Em 1949, o Prof. Dr. Murray Barr da University Of Western Ontario, juntamente com seu assistente Prof. Dr. E. G. Bertram, mostraram que uma massa de cromatina (cromossomo enovelado), há muito tempo identificada, mas pouco compreendida, no núcleo das células nervosas, estava freqüentemente presente em fêmeas mas não nos machos (Fig 4).

Figura 4: a) Célula Feminina

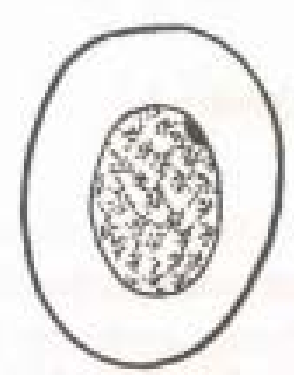

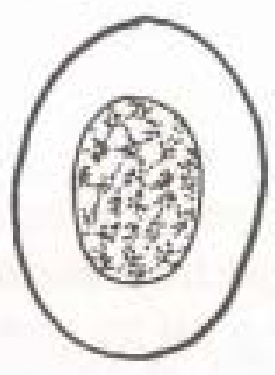

b) Célula Masculina
A cromatina sexual está presente quando existem dois ou mais $X$ e o número de corpúsculo de cromatina sexual é o número de cromossomos $X$ menos um. Com isso, então, passa a cromatina sexual a ser outra característica que determina 0 sexo.
A partir de agora, importa levar em consideração que o sexo cromossômico não é indicador final do sexo no qual o indivíduo deve ser enquadrado. São fatores muito mais importantes na decisão do fenótipo atual do sexo de criação 


\section{Glossário}

AUTOSSOMO - cromossomo diferente dos cromossomos sexuais.

CROMOSSOMO - corpúsculo presente de forma constante no núcleo celular, estrutura que carrega os genes.

CROMOSSOMIA - relativo à ação cromossômica.

CROMOSSOMOS HOMÓLOGOS - refere-se a cromossomos que estão emparelhados formando pares.

CROMOSSOMOS SEXUAIS - cromossomos que diferem os autossomos na espécie humana, XX, XY.

DIFERENCIAÇĀO - ato ou efeito de diferenciar-se; em citologia - alteração anatômica e funcional da célula.

FECUNDAÇĀO - ato ou efeito de fecundar, o mesmo que fertilizar.

FENÓTIPO - aspecto externo do organismo subordinado às influências do ambiente.

GENÓTIPO - conjunto de informação genética contida na massa hereditária.

GÔNADAS - glândulas genitais de um ou outro sexo: homem-testículos, mulher-ovários.

HEIEROGAMÉIICOS - aquele que apresenta gametas (espermatozóides) diferentes: $\mathrm{XeY}$.

HOMOGAMÉIICO - aquele que possui gametas iguais (óvulo).

HORMÔNIO - substância protéica ou lipídica que atua no sangue sobre as funçōes orgânicas como excitante ou regularizador.

INTER-SEXUADO - diz-se de indivíduos que fogem aos padrōes de normalidade sexual (anatômico, genético e psicossocial).

\section{Bibliografia}

ÁVILA, Vicente Fideles de. A pesquisa na dinâmica e na essência da universidade. Campo Grande: UFMS, (no prelo).

BARR, M. L Sexual dimorphism in interphase nuclei. American J. Human Genet, 1979. 